\title{
Do swingers self-identify as swingers when attending STI services for testing? A cross-sectional study
}

Citation for published version (APA):

Spauwen, L. W. L., Niekamp, A-M., Hoebe, C. J. P. A., \& Dukers-Muijrers, N. H. T. M. (2018). Do swingers self-identify as swingers when attending STI services for testing? A cross-sectional study. Sexually Transmitted Infections, 94(8), 559-561. https://doi.org/10.1136/sextrans-2017-053321

Document status and date:

Published: 01/12/2018

DOI:

10.1136/sextrans-2017-053321

Document Version:

Publisher's PDF, also known as Version of record

Document license:

Taverne

Please check the document version of this publication:

- A submitted manuscript is the version of the article upon submission and before peer-review. There can be important differences between the submitted version and the official published version of record.

People interested in the research are advised to contact the author for the final version of the publication, or visit the DOI to the publisher's website.

- The final author version and the galley proof are versions of the publication after peer review.

- The final published version features the final layout of the paper including the volume, issue and page numbers.

Link to publication

\footnotetext{
General rights rights.

- You may freely distribute the URL identifying the publication in the public portal. please follow below link for the End User Agreement:

www.umlib.nl/taverne-license

Take down policy

If you believe that this document breaches copyright please contact us at:

repository@maastrichtuniversity.nl

providing details and we will investigate your claim.
}

Copyright and moral rights for the publications made accessible in the public portal are retained by the authors and/or other copyright owners and it is a condition of accessing publications that users recognise and abide by the legal requirements associated with these

- Users may download and print one copy of any publication from the public portal for the purpose of private study or research.

- You may not further distribute the material or use it for any profit-making activity or commercial gain

If the publication is distributed under the terms of Article $25 \mathrm{fa}$ of the Dutch Copyright Act, indicated by the "Taverne" license above, 


\title{
Do swingers self-identify as swingers when attending STI services for testing? A cross-sectional study
}

\author{
Laura W L Spauwen, ${ }^{1}$ Anne-Marie Niekamp, ${ }^{1,2}$ Christian J P A Hoebe, ${ }^{1,2}$ \\ Nicole H T M Dukers-Muijrers ${ }^{1,2}$
}

- Additional material is published online only. To view please visit the journal online (http://dx.doi.org/10.1136/ sextrans-2017-053321).

'Department of Sexual Health, Infectious Diseases and Environmental Health, South Limburg Public Health Services, Heerlen, The Netherlands ${ }^{2}$ Department of Medical Microbiology, School of Public Health and Primary Care (CAPHRI), Maastricht University Medical Centre (MUMC+), Maastricht, The Netherlands

\section{Correspondence to}

Dr Nicole H T M DukersMuiirers, Department of Sexual Health, Infectious Diseases and Environmental Health, South Limburg Public Health Service, Geleen 6160HA, The Netherlands; nicole.dukers@ ggdzl.nl

Received 4 July 2017 Revised 15 December 2017 Accepted 15 January 2018 Published Online First 30 January 2018

\begin{abstract}
Objectives Swingers, that is, members of a heterosexual couple who, as a couple, had sex with other couples and/or singles within the swinger's subculture, are a hidden population with substantial rates of sexually transmitted infections (STIS) and high-risk sexual behaviour. Information on swingers' self-identification to be a swinger, their risk perception and attitudes about STI testing and safe sex will help to reveal swingers who are hidden while in care, to address them with targeted strategies.
\end{abstract}

Methods We used data from a convenience sample of 289 swingers from our Dutch STI clinic patient registry between 2009 and 2012 (median age 45 years; 49\% women; STI positivity $13 \%$, no condom in vaginal sex: $57 \%$ ). Participants filled in a self-administered questionnaire on sexual behaviour and answered statements about self-identification, risk perception and attitudes about STI testing and safe sex.

Results of all participating registered swingers, 56\% self-identified as a swinger. Safe sex was reportedly deemed important (77\%). Overall, 72\%, 62\% and $56 \%$ reported that STI testing, partner notification and condom use is the norm in the swinger community. The latter was reported more often by self-identified swingers compared with non-self-identified swingers. Self-identified swingers further swinged more often, had more partners and more often swinged at home parties than non-self-identified swingers.

Conclusions About half of STI clinic attending swingers whose sexual behaviour agrees with the definition of swinging are neutral/do not identify themselves to be a swinger. As many STI clinics internationally not specifically ask clients about their swinging behaviour, swingers may be a missed target population in care. Implementation of routine questions addressing behaviour (thus not only asking whether someone is a swinger) in STI clinics is feasible and facilitated by swingers' positive norm towards STI prevention and testing. Implementing routine swinger questions contribute to effective STI services including appropriate testing, counselling and partner notification.

\section{INTRODUCTION}

Swingers, that is, members of a heterosexual couple who, as a couple, had sex with other couples and/ or singles within the swinger's subculture, are a generally older group that show high rates of sexually transmitted infections (STIs) and sexual risk behaviour, like multiple sex partners, group sex and drug use. ${ }^{1-4}$

They are an important target population for STI control strategies for Chlamydia trachomatis (CT) and Neisseria gonorrhoeae (NG), with about 1 in 10 having STI diagnosed as assessed in the Netherlands and UK. ${ }^{25-7}$

However, swingers are under-recognised in healthcare. ${ }^{156}$ In previous work, we aimed to assess STI prevalence in Dutch swingers attending STI clinics, ${ }^{25}$ risk factors for STI ${ }^{14}$ and the proportion of swingers who are under-recognised in our current STI care. ${ }^{56}$ We demonstrated substantial STI prevalence and the association with drug use. Notably, studies in the UK, Belgium and Canada showed that substantial numbers of swingers did not attend testing facilities. ${ }^{6-8}$ When swingers attend testing services, we need to reduce under-recognition to deliver appropriate care. Therefore, we here have assessed swingers' self-identification, risk perception and attitudes in a clinic setting in which questions are routinely asked about swinging behaviour. The results will help to identify swingers in care and to address them more effectively in STI control strategies.

\section{MATERIALS AND METHODS Study population}

We used data from the SWAP study on individuals who were included as a swinger in the patient STI clinic registry for testing (South Limburg Public Health Service, the Netherlands). ${ }^{4}$ Swingers were identified by the nurse asking questions including 'are you a swinger?', 'do you practice partner-swapping?', 'do you have sex with other couples together with your partner?' and 'do you visit sex clubs for couples?'.

From 2009 to 2012, we approached swingers attending the clinic for participation. Swingers were eligible to be included when they were registered as a swinger in the patient registry and reported swinging activity in the past year. This paper presents data from the resulting convenience sample of 289 swingers who agreed to participate $28 \%$ of in total 1023 swingers registered). Of the 289 participants, $49 \%$ were women and their median age was 45 years (IQR 38-50 years). The cumulative yearly $\mathrm{CT} / \mathrm{NG}$ prevalence was $13 \%$. These characteristics were not statistically different from the swingers at our clinic who did not participate $(51 \%$ were women, median age was 42 years (IQR 37-47)). 


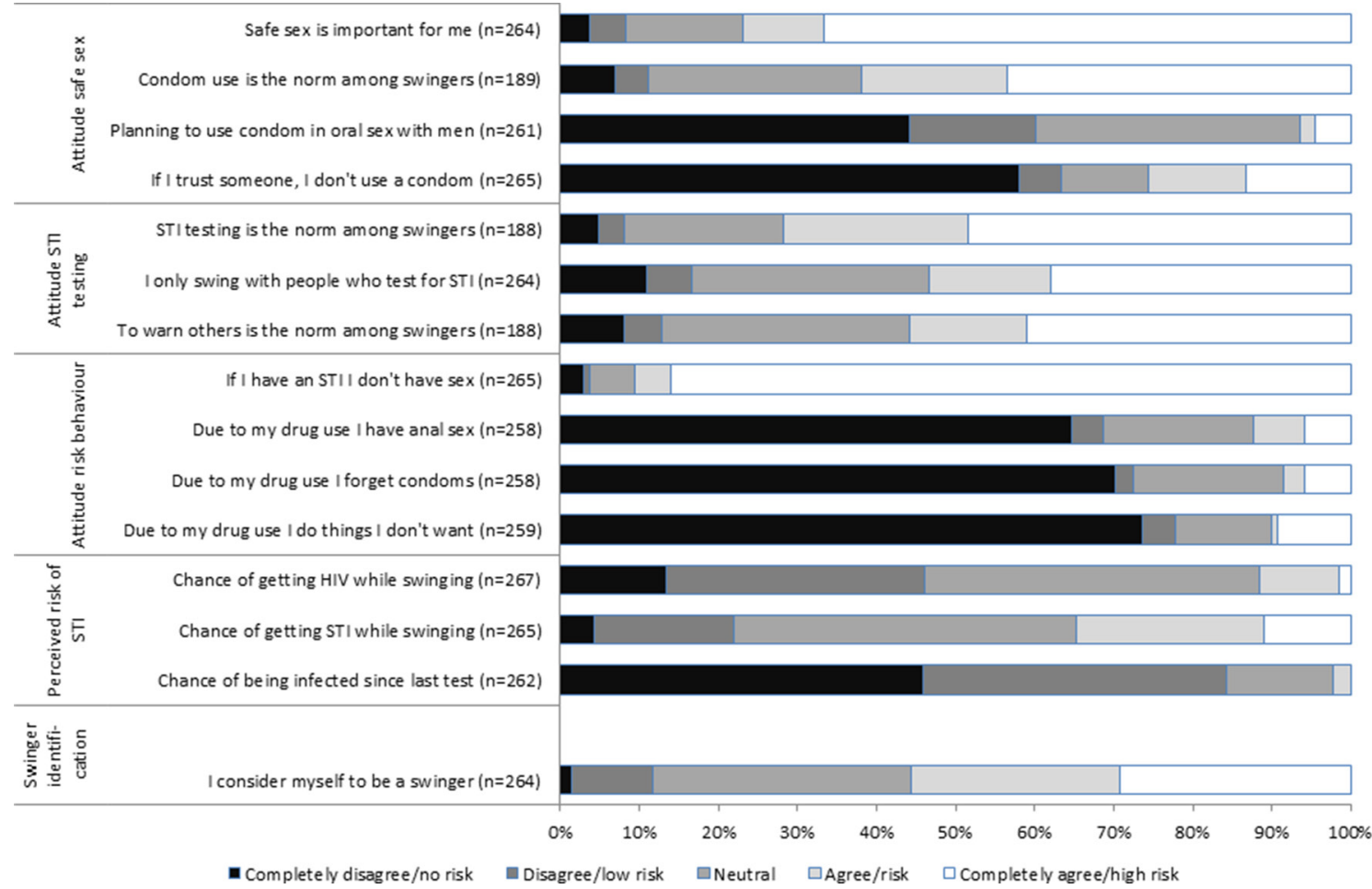

Figure 1 Number of swingers at a Dutch STI clinic who completely disagree (black) to completely agree (white) with statements about selfidentification, risk perception and attitudes about STI testing, risk behaviour and safe sex with regard to swinging. Completely disagree/no risk; Disagree/low risk; Neutral; Agree/risk; Completely agree/high risk.

The CT/NG prevalence in non-participants was somewhat lower $(10 \%)$ yet was based on a single clinic consultation.

Medical ethical approval was obtained in 2009 from the Medical Ethical Committee of Maastricht University Medical Centre (MUMC+) (NL23703.068.08), and participants gave written informed consent.

\section{Questionnaire and analyses}

We collected information using a self-administered questionnaire. ${ }^{14}$ The questionnaire included statements on swinger self-identification, risk perception and attitudes about STI testing and safe sex (see figure 1). All items could be answered on a five-point Likert scale (ranging from completely disagree/ no risk to completely agree/high risk). Three items (condom use, STI testing and the norm to warn others) were asked in a specific time period (2009-2010) only and missing for some participants. Missing data ranging from $8 \%$ to 35\% were not included in the calculations (see figure 1 for $\mathrm{n}$ included). The proportions missing were similar between the three categories of the outcome variable of swinger self-identification (of which $8 \%$ was missing) (all $\mathrm{P}>0.05$ ).

As described previously, ${ }^{14}$ other questions include demographics, type of sex, group sex, condom use and number of partners during the last 6 months.

We identified the relative frequency of the answers given, shown in figure 1 . We then dichotomised the variables into 'disagree' (completely disagree, disagree, neutral) and 'agree' (completely agree and agree) to compare (using $\chi^{2}$ tests) characteristics, attitudes and perceptions about swinging between swingers who did not self-identify (disagreed or completely disagreed), swingers who were neutral on self-identification and swingers who self-identified as swinger (agreed or completely agreed). Results are presented in the online supplementary table.

\section{RESULTS}

Characteristics and behaviour of the 289 participants have been described before by Spauwen et al. ${ }^{1}$ In short, $27 \%$ of men and $77 \%$ of women reported same-sex activities. Fifty-six per cent reported group sex. Fifty-four per cent reported six or more recent sex partners and $57 \%$ did not use a condom during vaginal sex. ${ }^{1}$

\section{Swinger identification}

When visiting the STI clinic, 100\% of the participants were identified as swingers in consultation with the clinic nurse, and all were registered as swinger in the patient registry.

Among the swingers participating in our study, 56\% $(n=147)$ did self-identify as a swinger; $32.6 \%(n=86)$ were neutral and $11.7 \%(n=31)$ did not self-identify as a swingers.

Self-identified swingers more often swinged frequently (ie, six times or more in the past 6 months), had many (six or more) swinging partners and practised swinging at home parties (online supplementary table).

\section{Attitude safe sex}

Safe sex is important for $77 \%$ of the participating swingers. Sixty-two per cent (completely) agreed that condom use is the norm in the swinger community; this was $50 \%$ in swingers who did not identify themselves as swinger, 51\% in swingers who were neutral on self-identification and $72 \%$ in swingers who self-identified as swinger. Just $7 \%$ were planning to always use a condom in oral sex with men.

\section{Attitude STI testing}

STI testing is the norm in the swinger community according to $72 \%$ of the participants. Half of them $(53 \%)$ only practised 
swinging with people who tested for STIs (as they did). Fifty-six per cent agreed that warning others in case of an STI is the norm in the swinger community.

\section{Attitude risk behaviour}

About 1 in 10 swingers reported that due to using drugs they had anal sex (12\%), forgot to use a condom (9\%) and did things against their will (10\%).

\section{Perceived risk of STI}

Twelve per cent of swingers reported that there was a chance that they would acquire HIV during swinging and 35\% that there was a chance for acquiring an STI. Only 2\% reported that there was a chance that they had acquired an STI themselves after their last STI test.

\section{DISCUSSION}

This is the first study to assess self-identification to be a swinger in swingers who attended an STI clinic for testing. In this context, care providers identified swingers by routinely asking all their clients several questions, that is, on swinging behaviour and on being a swinger. The main finding is that only about half of the swingers who were registered as a swinger in care according to their swinging behaviour also self-identified as a swinger.

A limitation of this study is that the information was self-reported, which may introduce recall and social desirability bias. Multiple comparisons were conducted potentially revealing differences due to chance, but on the other hand, the relatively small sample size may have precluded finding differences altogether. Further, some variables had missing data although missing data were evenly distributed over the outcome variable of swingers' self-identification. Still, the possibly selected study population makes it difficult to know if these findings are generalisable to swingers attending other STI clinics or do not attend STI clinics. For example, a UK population-based study ${ }^{8}$ demonstrated that the majority of the swingers $(n=91,68 \%)$ had not attended a sexual health clinic. ${ }^{7}$ Nevertheless, to the best of our knowledge, this study is the largest study of swingers and provides leads for improved sexual healthcare.

Self-identification likely is even lower in the wider group of swingers including those who do not (regularly) test for STIs. Swingers who did not identify themselves as such swinged less often and had fewer partners than swingers who self-identified as swinger. Condom use was less often the norm in those who did not self-identify as swinger. Notably was that overall, most swingers agreed that safe sex is important, yet, less than half of the swingers reported condom use during vaginal sex. ${ }^{1}$ Qualitative research suggests that rules regarding condom use in swinging encounters are less frequently established and/or adhered to. ${ }^{6910}$ Secrecy, stigma and taboo surrounding swinging, and privacy rules in the swinging subculture may play a role and should be taken into account when addressing swingers in clinical settings or in other STI testing interventions. ${ }^{6} 910$

An encouraging finding is that a substantial proportion reported that partner notification is the norm. In swingers who have dense sexual networks, partner notification can be a highly effective strategy. Yet, the first step is to recognise swingers in the clinical care setting by routinely including questions on swinging behaviour and not merely rely on self-identification.

In conclusion, our findings emphasise the importance of identifying swingers when they are in care by asking about swinging behaviour and not only about their self-identification. Therefore, we will be able to improve counselling, testing and partner notification for swingers, especially those who do not reveal themselves at sexual health services.

\section{Handling editor Jackie A Cassell}

Acknowledgements We would like to thank the staff of the South Limburg STI clinic for their valuable contribution to data collection.

Contributors LWLS analysed the data and drafted the manuscript. NHTMDM drafted the manuscript and supervised the study. AMN was involved in the data collection. AMN and CJPAH contributed to revising the draft critically for important intellectual content. All authors substantially contributed to the conception or design of the work and to the acquisition, analysis or interpretation of data. All authors provided final approval of the version to be published. All authors agree to be accountable for all aspects of the work in ensuring that questions related to the accuracy or integrity of any part of the work are appropriately investigated and resolved.

Competing interests None declared.

Patient consent Obtained.

Ethics approval Medical Ethical Committee of Maastricht University Medical Centre.

Provenance and peer review Not commissioned; externally peer reviewed.

(c) Article author(s) (or their employer(s) unless otherwise stated in the text of the article) 2018. All rights reserved. No commercial use is permitted unless otherwise expressly granted.

\section{REFERENCES}

1 Spauwen LW, Niekamp AM, Hoebe CJ, et al. Drug use, sexual risk behaviour and sexually transmitted infections among swingers: a cross-sectional study in The Netherlands. Sex Transm Infect 2015;91:31-6.

2 Dukers-Muijrers NH, Niekamp AM, Brouwers EE, et al. Older and swinging; need to identify hidden and emerging risk groups at STI clinics. Sex Transm Infect 2010;86:315-7.

3 Jenks RJ. Swinging: a review of the literature. Arch Sex Behav 1998;27:507-21.

4 Niekamp A-M, Mercken LAG, Hoebe CJPA, et al. A sexual affiliation network of swingers, heterosexuals practicing risk behaviours that potentiate the spread of sexually transmitted infections: a two-mode approach. Soc Networks 2013;35:223-36

5 Dukers-Muijrers N, van Rooijen MS, Hogewoning A, et al. Incidence of repeat testing and diagnoses of Chlamydia trachomatis and Neisseria gonorrhoea in swingers, homosexual and heterosexual men and women at two large Dutch STI clinics, 2006-2013. Sex Transm Infect 2017;93:383-9.

6 Mercer CH. Swinging: if you do not ask you may not find, but you need to. Sex. Transm. Infect; 0:1-2.

7 Platteau T, van Lankveld J, Ooms L, et al. Sexual behavior and sexually transmitted infections among swingers: results from an online survey in Belgium. J Sex Marital Ther 2017;43:709-19.

8 Natsal. The national survey of sexual attitudes and lifestyles. http://www.natsal.ac.uk (accessed 10 Apr 2017).

9 Kimberly C, Hans JD. From fantasy to reality: a grounded theory of experiences in the swinging lifestyle. Arch Sex Behav 2017;46:789-99.

10 de Visser R, McDonald D. Swings and roundabouts: management of jealousy in heterosexual swinging couples. Br J Soc Psychol 2007;46:459-76. 